\title{
The depiction of acromegaly in ancient Greek and Hellenistic art
}

\author{
Konstantinos Laios, ${ }^{1}$ Maria Zozolou, ${ }^{2}$ Konstantinos Markatos, ${ }^{3}$ \\ Marianna Karamanou, ${ }^{1}$ George Androutsos ${ }^{1}$
}

${ }^{1}$ Biomedical Research Foundation, Academy of Athens, ${ }^{2}$ Medical School, National and Kapodistrian University of Athens, ${ }^{3}$ Henry Dunant Hospital, Orthopedics Department, Athens, Greece

Dear Editor,

In 1886, Pierre Marie (1853-1940) published the first accurate scientific description of acromegaly while also coining the term that we now employ (acromegaly today being used when the disease appears in adulthood, and gigantism when it is seen in childhood). While several other physicians had, previous to Marie, spoken about this disease, starting with the Dutch physician Johann Wier (ca. 1515-1588), ${ }^{1}$ numerous representations of the human figure with characteristics of acromegaly were fashioned by ancient Greek and Hellenistic craftsmen. For example, five terracotta male figurines of the ancient Greek era (Alexandria, Graeco-Roman Museum: 10039 Figure 1 and 22631, Delos, Archaeological Museum: A 1817, Vaticano, Museo Gregoriano Etrusco: 13687, Geneva, Collection De Candolle: 21) and three terracotta female figurines (Taranto, Museo Nazionale Archeologico, Figure 2 Athens, Benaki Museum: 8210, Tarsus, Tarsus Museum: 35-1369) dated to the

Key words: Acromegaly, Ancient Greek art, Ancient Greek medicine, Hellenistic art, Terracotta figurines

Address for correspondence:

Konstantinos Laios PhD, 1 Athinodorou Str., Kato Petralona, 11853 Athens, Attiki, Greece; Tel.: +30 6947091434, Fax:+30 2103474338, E-mail: konstlaios@gmail.com Received: 15-11-2016, Accepted: 18-11-2016
Hellenistic age (323-31 BC), all with the characteristics of acromegaly, have been found in various parts of the ancient Greek world of the times. ${ }^{2}$ All these

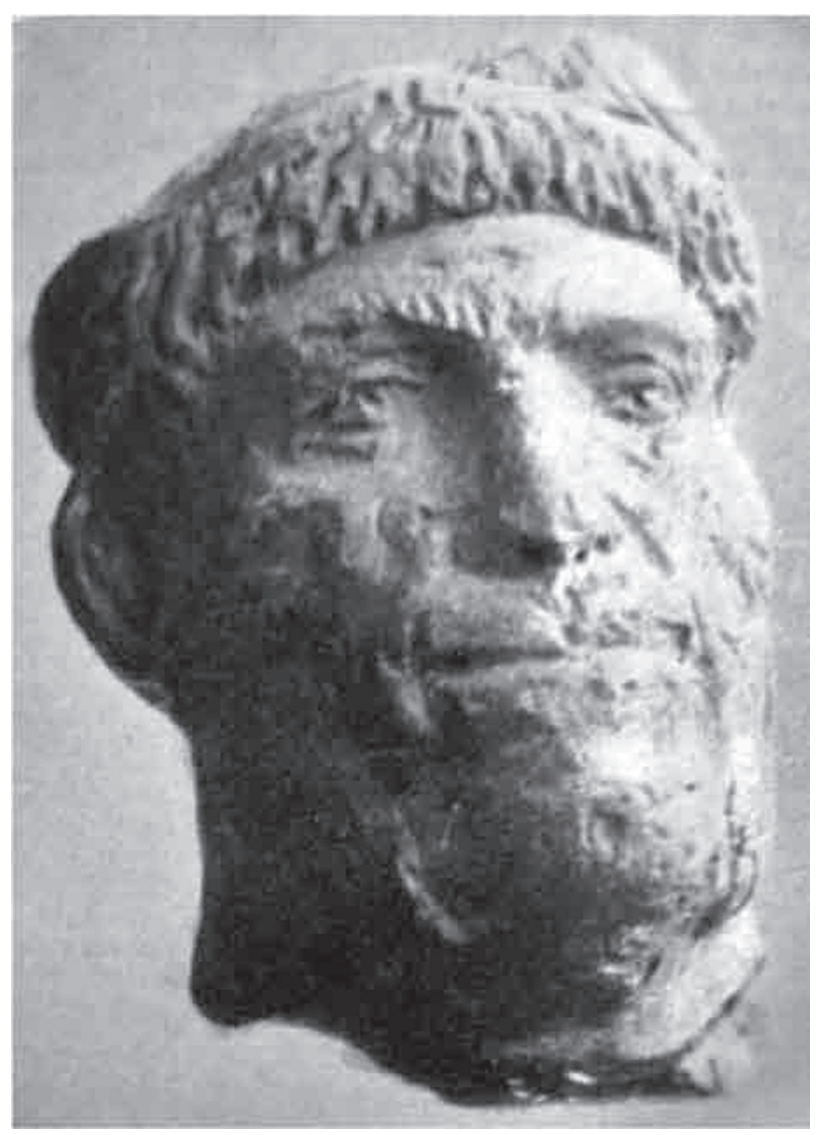

Figure 1. Hellenistic male terracotta figurine showing the characteristics of acromegaly. 


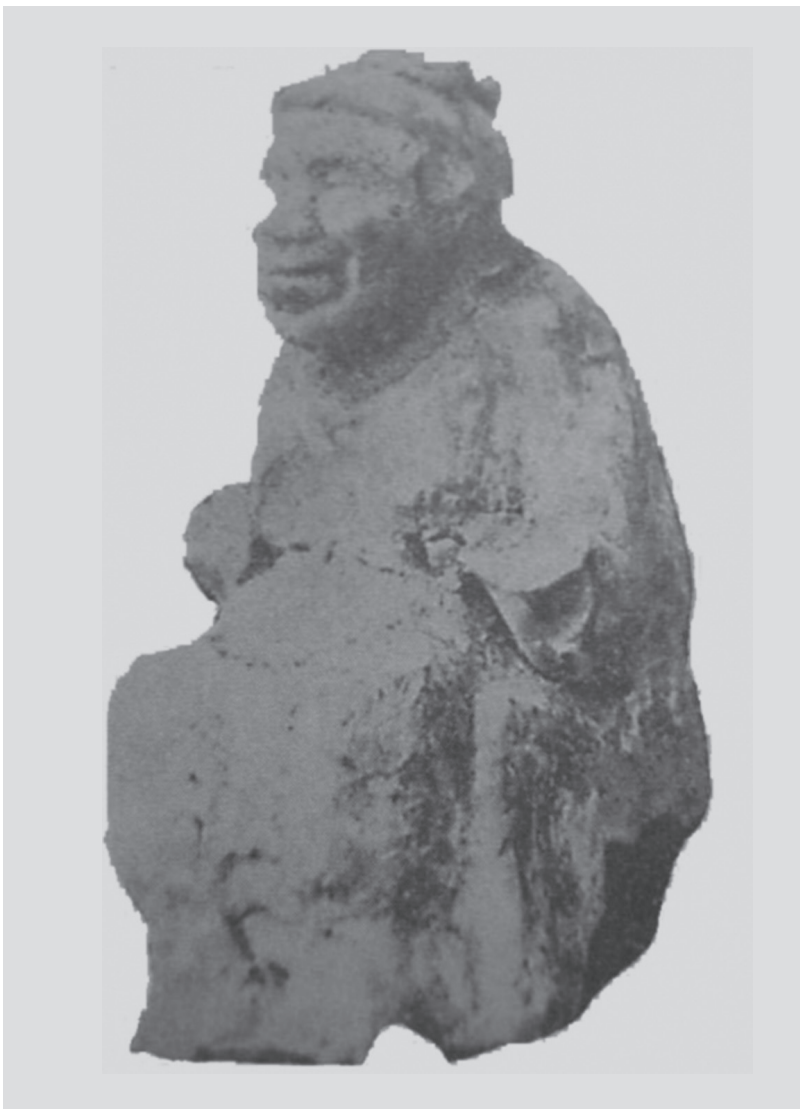

Figure 2. Hellenistic female terracotta figurine showing the characteristics of acromegaly.

figures present an elongated forehead or jaw which are typical of acromegaly. Moreover, it is clear that the age of the persons represented in these figurines is over 40 years, middle age being the time of life when acromegaly, because of its insidious onset and slow progression, normally first becomes evident.

Ancient Greek and Hellenistic art includes a great number of pathological representations. While some belong in the categories of votive offerings or grotesque art, others have a distinctly 'clinical' value, they having either served as models for medical education or else provide realistic portrayals of people drawn from everyday life. Both these latter types interestingly display a wide range of pathologies, among them kyphosis, tuberculosis, cleft lip and acromegaly. ${ }^{2}$ With regard specifically to depictions of acromegaly, scrupulous study of the figures in question has determined that they should not be linked to any mythological characters, nor should they be considered merely as freakish or 'grotesque' figurines, i.e. they are not examples of the 'grotesque art' of the epoch. ${ }^{3}$ Instead, these representations in ancient Greek and Hellenistic sculpture and pottery are clearly of diseased individuals and hence demonstrate an intimate knowledge of the existence and appearance of this pathology, together with a wide variety of other ailments and disorders. Thus, although in ancient Greek medical literature there is no explicit description of acromegaly, we may deduce from the numerous examples of such depictions in ancient Greek and Hellenistic art and craftsmanship that acromegaly was well known in these as well as other ancient societies.

Of note, there is the misconception that certain facial deformations rendered in the likenesses of several Hellenistic and Roman emperors appearing on ancient coins ${ }^{4}$ represent acromegaly. We consider this conjecture to be mistaken, our view being that the heavy forehead and elongated jaw of these prestigious personages are characteristics meant to emphasize the power of the emperor whose authority is absolute. In a similar vein, a number of fantastical beings of ancient Greek mythology, for example monsters, ogres, giants and a diversity of bizarre creatures (human or animal) have no connection with any pathological condition, to cite a few, the Cyclopes, savage one-eyed giants, the Sirens, beautiful but dangerous part-human, part-bird creatures, Cerberus, a monstrous multi-headed dog, and the Hydra, a giant multi-headed serpent/water snake, pathology having no place in the context of ancient Greek mythology. ${ }^{5}$

\section{CONFLICT OF INTEREST}

The authors declare that there is no conflict of interest.

\section{REFERENCES}

1. Sternberg M, 1897 Akromegalie. Wien: Alfred Holder.

2. Laios K, 2015 Diseases and their iconography during antiquity. Athens: Saripoleion Library, 123 [Greek].

3. Stevenson WE, 1975 The Pathological Grotesque Representation in Greek and Roman Art. Diss. University of Pennsylvania.

4. Hart GD, 1973 The diagnosis of disease from ancient coins. Archaeology 26: 123-127.

5. Graf F, 1993 Greek Mythology: an introduction. Baltimore: Johns Hopkins University Press. 